\title{
Reporting Intersex Florets in Salix caprea L. (Salicaceae) from NE Anatolia
}

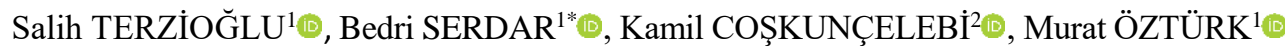 \\ ${ }^{1}$ Karadeniz Technical University, Faculty of Forestry, Department of Forest Botany, Trabzon, TURKEY \\ ${ }^{2}$ Karadeniz Technical University, Faculty of Science, Department of Biology, Trabzon, TURKEY \\ *Corresponding Author: bserdar@ktu.edu.tr
}

Received Date: 12.02.2019

Accepted Date: 06.01.2020

\begin{abstract}
Aim of the study: In the present paper, male or female catkins composed of several intersexes florets in four individuals (all in the same population) of Salix caprea are reported from Turkey for the first time.

Study area: Roadsides at Köse Mountain in Gümüşhane (NE Anatolia) wherein Scots pine forest is dominant.

Material and method: Plant materials were collected from the same population belong to goat willow during the excursion around Köse Mountain in 2017 and 2018. All materials consisting male, female and metamorfosans flowered shoots were first processed according to standard herbarium techniques.

Main results: Metamorphosans or intersexes florets in Salix caprea were recorded for the first time from Turkey.

Research highlights: In extremely rare cases, metamorphosans florets have been reported in several willow species distributed outside of Turkey. However, native goat willow individuals, in which these florets appear, were recorded here for the Turkish flora. Beside its possible reasons were discussed at local scale.
\end{abstract}

Keywords: Metamorphosans, Sex Change, Turkey, Willow

\section{İnterseks Çiçekli Salix caprea L. (Salicaceae)'nın Kuzeydoğu Anadolu'da Varlığı}

$\ddot{O} \mathbf{z}$

Çalışmanın amacı: Bu çalışmada, Salix caprea'nın interseks çiçeklere sahip erkek veya dişi kedicikli aynı popülasyondaki dört bireyinin varlığı Türkiye'den ilk kez bildirilmektedir.

Çallş̧ma alanı: Gümüşhane (Kuzeydoğu Anadolu)'de sarıçamın baskın olduğu Köse Dağı yol kenarlar1.

Materyal ve yöntem: Çalışma materyalleri, Köse Dağı'ndaki aynı keçi söğüdü popülasyonundan 2017 ve 2018 yıllarında gerçekleştirilen arazi çalışmalarında toplanmıştır. Erkek, dişi ve metamorfoz çiçekli sürgünlerin herbaryum örneklerinden oluşan tüm materyaller önce standart herbaryum tekniğine göre hazırlanmıștır.

Temel sonuçlar: Keçi söğüdünün metamorfoz veya interseks çiçeklerden oluşan çiçek kurullarına sahip bireyleri Türkiye'den kaydedilmektedir.

Önemli vurgular: Ülkemiz dışındaki kimi söğüt türlerinde metamorfoz çiçekler çok nadir olarak gözlenmektedir. Bu çalışmada ise metamorfoz çiçekli doğal keçi söğüdü bireyleri Türkiye florasına kaydedilmiştir. Bu durumun olası nedenleri çalışma alanındaki dinamikler çerçevesinde tartışılmıştır.

Anahtar kelimeler: Metamorfoz, Cinsiyet Değişsimi, Türkiye, Söğüt

\section{Introduction}

Though disagreement on the number of Salix L. (willow) species, the genus consists of approximately 450 species mainly distributed in Northern hemisphere (Argus, 2010) and 27 of them are native to Turkey (Güner et al., 2012; Terzioğlu et al., 2014). Willows are ordinarily known as dioecious plants including some extreme abnormalities.
Although the strictly dioecious breeding system with distinct pure both female (with pistillate catkins only) and male (with staminate catkins only) individuals is predominating in willows, some unusual situations observed in some Salix taxa (Smith, 1940; Skvortsov, 1999; Rottenberg, 2007). A significant number of willows are reported that the specimens show some 
exceptions from strictly dioecious condition such as intersex (Smith, 1940; Mirski, 2014; Harrison, 1924; Myers-Smith \& Hik, 2012; Mirski \& Brzesko, 2014). Intersexualism is important for genetic diversity in plants. Depending both on natural and artificial factors, 18 willow species showing exceptions from dioecy (Mirski, 2014) which is important for evolutionary biology.

Salix caprea L. (goat willow) is a deciduous small to medium-size tree or shrub among the widespread native species in Turkey (Skvortsov \& Edmondson, 1982). Its general distribution spreads from Spain to China, from Turkey to Northern Iran (Meusel et al., 1978). The goat willow is a pioneer and a fast-growing plant. Regarding its demand for light, it is a very shade intolerant species, occurring in open areas with full sun, but it is one of the few willow species able to grow in forest (Enescu et al., 2016).
During the excursion study around Köse Mountain in 2017, the authors collected some samples belong to goat willow with unusual catkins. A close examination and literature survey showed that this kind of catkins were reported previously in S. caprea distributed outside of Turkey (Harrison, 1924). Further field study around Köse Mountain in 2018 revealed that this kind of catkins are present in four individuals of $S$. caprea distributed in the mountain range of Köse (Gümüşhane). Present findings are the first to report intersex florets in Salix caprea distributed in Turkey.

\section{Materials and Methods}

Samples were collected from Pinus sylvestris L. forest in Köse Mountain (A7 Gümüşhane) in 2017 and 2018. Locality information regarding to unusual specimen were given in Figure 1 and Table 1.

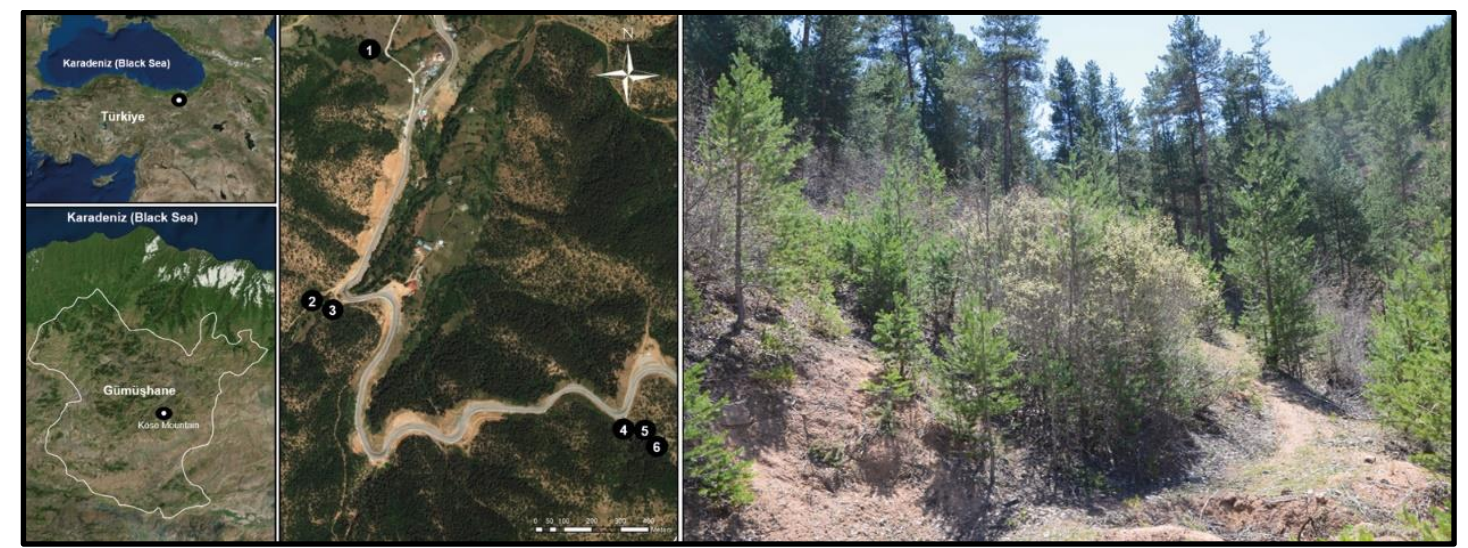

Figure 1. Location of population of studied intersex (with the numbers 1 to 4), and male/female individuals (with the number 5 and 6) respectively, and a view from habitat in Köse Mountain / Gümüşhane.

All specimens were first processed according to standard herbarium techniques and then identified by using Flora of Turkey (Skvortsov \& Edmondson, 1982) and deposited in the Herbarium of Karadeniz Technical University, Faculty of Forestry (KATO). Terminology of intersexes or metamorphosans were firstly used by Heribert-Nilsson (1918) and Rainio (1927) respectively.
Table 1. Studied specimens of Salix caprea from Köse Mountain

\begin{tabular}{ccccc}
\hline No & $\begin{array}{c}\text { Gender of } \\
\text { catkin }\end{array}$ & $\begin{array}{c}\text { KATO } \\
\text { number }\end{array}$ & $\begin{array}{c}\text { Coordinates } \\
(\mathrm{UTM})\end{array}$ & $\begin{array}{c}\text { Altitude } \\
(\mathrm{m})\end{array}$ \\
\hline 1 & Intersex & 20776 & $\begin{array}{r}0547251, \\
4462149\end{array}$ & 1721 \\
\hline 2 & Intersex & 20777 & $\begin{array}{r}0547132, \\
4461472\end{array}$ & 1748 \\
\hline 3 & Intersex & 20778 & $\begin{array}{r}0547153, \\
4461471\end{array}$ & 1750 \\
\hline 4 & Intersex & 20779 & $\begin{array}{r}0547973, \\
4461143\end{array}$ & 1873 \\
\hline 5 & Male & 20780 & $\begin{array}{r}0547978, \\
4461142\end{array}$ & 1878 \\
\hline 6 & Female & 20781 & $\begin{array}{r}0547986, \\
4461137\end{array}$ & 1881 \\
\hline
\end{tabular}




\section{Results and Discussion}

Specimens with male and female (Figure 2 a,b), and unusual catkins (Figure $2 \mathrm{c}, \mathrm{d}, \mathrm{e}, \mathrm{f}$ ) are present in the same habitat in Köse Mountain (Gümüşhane). At first glance, some male individuals were observed with male catkins which have metamorphosans female florets (Figure $2 \mathrm{c}, \mathrm{d}$ ). Rest of the field studies, authors came across the other individuals. They have both female catkins with metamorphosans male florets and mixed ones (Figure 2 e, f). Metamorphosans or intersexes florets (Figure g, h, i) were obtained from these catkins and photographed in detail. Our observations are in accordance with Harrison (1949) who reported intersex individuals with $10 \%$ of catkins consisting both pistillate and staminate florets in S. caprea.

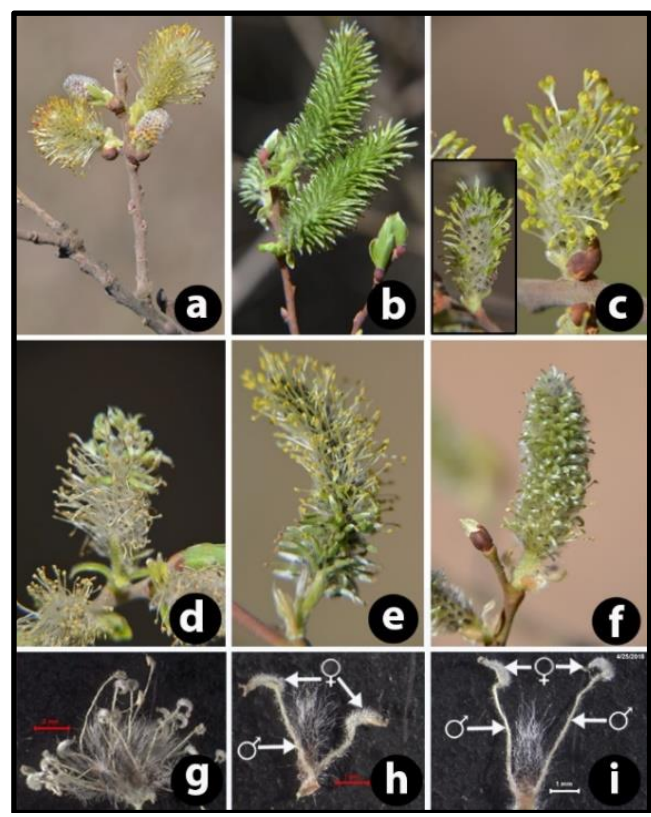

Figure 2. Catkins of Salix caprea: a- Male catkins; b- Female catkins; c,d,e,f- Extraordinary catkins consist of intersexual or metamorphosans types of florets; $\mathbf{g}, \mathbf{h}$, i- Distinct filaments together with the anthers take on the appearance of abnormal ovaries

In the genus Salix (comprises dioecious species) the sexes are normally separate having pistillate or staminate flowers. Small minority of sexual organisms, which are geographically and taxonomically widespread, may change their sex (including dioecious) during their lifetime (Policansky, 1982; Martinez et al., 2018). Significant changes in metabolism of the plant, depending on environmental factors, is reported the reason of sex change (Mirski, 2014). Furthermore, anthropogenic habitat change can also be of importance (Faliński, 1998). Eriophyid mites (as parasite) is reported to change both sex from male to female (Harrison 1924) and leaf characteristics (Mosbacher et al., 2013) in some willow taxa. As well, many reports cited the similar modifications of sex changes due to both of insects and indirect action of fungi which produce effected chemical substances (Loehwing, 1938; Smith, 1940).

Such sex changes are reported in different Salix species, such as S. alba, S. fragilis, $S$. pentandra, $S$. aurita, $S$. cinerea and $S$. caprea (Harrison, 1924), S. podophylla, S. brachycarpa and S. pseudolapponum (Smith, 1940). Regular hermaphroditism was reported in $S$. martiana by Rohwer \& Kubitzki (1984). Metamorphosans florets as reported in the present study are one of the other handicaps that they not reflect the original generative characters of the taxa. According to Harrison (1949) and Mirski (2014), global climate changes, road construction/maintenance and grazing may cause such sexual changes in flowering 
plants. Road construction together with other anthropogenic factors may cause sexual changing in goat willow distributed in Köse mountain. Depending on regional climate model, in the next century, the temperature and precipitation will increase $2-4{ }^{\circ} \mathrm{C}$ and 200-300 mm, respectively for the mountainous range of Eastern Black Sea region wherein the study area stay (Terzioğlu et al., 2015). This is possibly among the threats likely to results alteration of generative organs of the reported willow individuals examined in the present paper.

\section{References}

Argus, G.W. (2010). Salix L. In: Flora of North America. Eds. Editorial Committee. Oxford University Press, New York and Oxford. 4157. http://www.efloras.org/ florataxon. aspx? flora_id=1\&taxon_id=129059

Enescu, C. M., Houston Durrant, T., de Rigo, D., Caudullo, G. (2016). Salix caprea in Europe: distribution, habitat, usage and threats. In: European Atlas of Forest Tree Species. Eds. San-Miguel-Ayanz, J., de Rigo, D., Caudullo, G., Houston Durrant, T., Mauri, A. (Eds.), Publ. Off. EU, Luxembourg. 170-171.

Faliński, J.B. (1998). Androgyny of individuals and polygamy in populations of Salix yrsinifolia Salisb. in the south-western part of its geographical range (NE-Poland).

Perspectives in Plant Ecology, Evolution and Systematics, 1/2, 238-266.

Güner, A., Aslan S., Ekim T., Vural M., Babaç MT. (edlr.) (2012). Türkiye Bitkileri Listesi (Damarlı Bitkiler). İstanbul, Türkiye: Flora Araştırmaları Derneği.

Harisson, J.H. (1924). Sex in the Salicaceae and its modification by Eriophid mites and other influences. The British Journal of Experimental Biology, 1, 445-472.

Harrison, J.H. (1949). Intersexuality in Irish Willows. The Irish Naturalists' Journal, 9(10), 268-272.

Heribert-Nilsson, N. (1918). Experimentelle studien ueber Variabilitaet, Spal- tung, Artbildung und Evolution in der Gattung Salix. Lunds. Univ. Arskr., 14, 28.

Loehwing, W.F. (1938). Physiological aspects of sex in angiosperms. Botanical Review, 4(11), 581-625.

Martinez, B., Sanin, M.J., Castillo, L.S., Camacho, R.L., Bernal, R. (2018). Sex change in the dioecious palm Ceroxylon quindiuense (Arecaceae). Ecology, 99(6), 1501-1503.
Meusel, H., Jager, E., Rauschert, S., Weinert, E. (1978). Vergleichende Chorologie der Zentraleuropaischen Flora, Gustav Fischer Verlag Jena.

Mirski, P. (2014). Exceptions from dioecy and sex lability in genus Salix. Dendrobiology, 71, 167-171.

Mirski, P. \& Brzesko, E. (2014). Are hermaphrodites better adapted to the colonization process in trioecious populations of Salix myrsinifolia? Acta Societatis Botanicorum Poloniae, 84(2), 167-175.

Mosbacher, J.B., Schmidt, N.M., Michelsen, A. (2013). Impacts of eriophyoid gall mites on arctic willow in a rapidly changing Arctic. Polar Biol. 36, 1735-1748.

Myers-Smith, I.H., \& Hik, D.S. (2012). Uniform Female-biased sex ratios in alpine willows. American Journal of Botany, 99(7): 12431248.

Policansky, D. (1982). Sex change in plants and animals. Annual Review of Ecology and Systematics, 3, 471-495.

Rainio, A.J. (1927). Ueber die Intersexualitaet bei der Gattung Salix. Ann. Zool. Botanicae Fennicae, 5(2), 265-275.

Rohwer, J. \& Kubitzki, K. (1984). Salix martiana, a Regularly Hermaphrodite Willow. Plant Systematics and Evoluation, 144, 99101.

Rottenberg, A. (2007). Fertility and sexual structure in a polygamous willow population. Plant Systematics and Evoluation, 268: 257260.

Smith, E.C. (1940). Sex expression in willows. Botanical Gazette, 101(4), 851-861.

Skvortsov, A.K. (1999). Willows of Russia and adjacent countries: taxonomical and geographical revision. University of Joensuu, Joensuu, Finland.

Skvortsov, A.K. \& Edmondson, J.R. (1982). Salix L. In: Davis, P.H. Flora of Turkey and the East Aegean Islands, vol: 7, at the University Press, Edinburgh, 694-716.

Terzioğlu, S., Serdar, B., Karaköse, M., Coşkunçelebi, K., Gültepe, M. (2014). New data on Salix anatolica (Salicaceae) endemic to Turkey. Phytotaxa, 167(1), 111-118.

Terzioğlu, S., Tüfekçioğlu, A., Küçük, M. (2015). Vegetation and plant diversity of HighAltitude Mountains in Eastern Karadeniz (Black Sea) Region of Turkey and climate change interactions. In: Climate Change Impacts on High-Altitude Ecosystems. Eds. Öztürk, M., Hakeem, K.R., Farudah-Hanum, I. and Efe, R., Springer International Publishing Switzerland, 383-408. 